ЦИФРОВИЙ ІНСТРУМЕНТАРІЙ УЧИТЕЛЯ ІНФОРМАТИКИ

\title{
DIGITAL TOOLS FOR COMPUTER SCIENCE TEACHER
}

у статmі розглянуто особливості використання цифрових інструментів у процесі організації змішаного та дистанційного навчання в умовах карантину в режимі онлайн. Описано можливості застосування платформи Moodle у дистаниійній освіті у Тернопільському національному педагогічному університеті імені Володимира Гнатюка. Розглянуто класифрікацію цифррових засобів навчання. Визначено критерї доступності та сумісності, універсальності та безпечності цифррових інструментів для створення тематичного кейсу або цифрового портороліо вчителя інфрорматики. Наведено структуру основних блоків платорорми Moodle, особливості їх фуннціонального призначення та можливості використання для створення електронних навчально-методичних комплексів. Подано перелік основних груп цифррових інструментів для ефективного впровадження дистаниійного навчання. Описано особливості організації та проаналізовано добірку інструментів для забезпечення комунікації вчителя 3 учнями, проведення відеоконферениій i вебінарів, програмних засобів для створення комп'ютерних презентацій, віртуальних інтерактивних дошок і книг, застосунків для складання ребусів, пазлів, кросвордів, розробки інтерактивних завдань та плакатів, засобів інформування школярів, наповнення баз тестових запитань і проведення підсумкового контролю в онлайн-фрорматі. Описано специфріку організації комунікативного простору з використанням цифрових інструментів. Розглянуто доцільність поєднання лекційних, практичних і лабораторних занять в синхронному й асинхронному фрорматі в умовах дистаниійної форми організації освітнього процесу. Визначено з практичного досвіду, що раціональне використання цифрових інструментів на онлайн-році допомагає вчителю забезпечити якісний освітній процес $і$ налагодити тісну співпрацю з учнями класу в умовах дистанційного навчання.
Ключові слова: дистанційне навчання, цифрові інструменти, інтерактивні засоби навчання, цифрове портфроліо, платфрорма Moodle, Zoom.

The article considers the peculiarities of the use of digital tools in the process of organizing blended and distance learning in quarantine online. The possibilities of using the Moodle platform in distance education at Ternopil Volodymyr Hnatiuk National Pedagogical University are described. The classification of digital teaching aids is considered. The criteria of availability and compatibility, universality and safety of digital tools for creating a thematic case or digital portfolio of a computer science teacher are defined. The structure of the main blocks of the Moodle platform, features of their functional purpose and possibilities of use for creation of electronic educational and methodical complexes are resulted. The list of the main groups of digital tools for effective implementation of distance learning is given. Features of the organization are described and a selection of tools for teacher communication with students, video conferencing and webinars, software for creating computer presentations, virtual interactive whiteboards and books, applications for puzzles, crosswords, development of interactive tasks and posters, tools informing students, filling in databases of test questions and conducting final control in online format. The specifics of the organization of communicative space with the use of digital tools are described. The expediency of combining lectures, practical and laboratory classes in synchronous and asynchronous format in the conditions of remote form of organization of educational process is considered. It is determined from practical experience that the rational use of digital tools in the online year helps the teacher to ensure a quality educational process and establish close cooperation with students in the classroom in a distance learning environment.

Key words: distance learning, digital tools, interactive learning tools, digital portfolio, Moodle platform, Zoom.

педагогічного університету

імені Володимира Гнатюка

Постановка проблеми у загальному вигляді. Всесвітня пандемія поставила перед освітянами ряд серйозних викликів та проблем, пов'язаних 3 переходом до дистанційного навчання у найкоротші терміни: організація освітнього простору для належного проведення занять у режимі онлайн, технічна підтримка та забезпечення комунікації між вчителями та учнями, можливості використання сучасних цифрових платформ, готовність учнів, вчителів та батьків до освоєння нових середовищ, цифрових ресурсів та доцільне їх використання для забезпечення якісного процесу навчання у нових умовах сьогодення.

Аналіз останніх досліджень і публікацій. Українські науковці активно досліджують проблему адаптації навчання до нових форм дистанційної освіти. Зокрема, проблему фрормування цифррових компетентностей у складних умовах діджиталізації проаналізували у своїх роботах Гриневич Л.М., Морзе Н.В., Бойко М.А., Генсерук Г.Р., Мартинюк С.В., Балик Н.Р. [1; 3]. Особливості використання цифрових інструментів на онлайн-уроках описано в роботах Іванюк І.В., Овчарук В.О., Барни О.В. [2; 4].

Виділення раніше невирішених частин проблеми. Міністерством освіти та науки України подано загальні методичні рекомендації щодо організації навчання у дистанційному форматі та можливостей використання в освітньому процесі цифррових інструментів. Однак залишається відкритим питання про вибір конкретних засобів для ефективної організації процесу навчання та комунікації з учнями, для забезпечення здобувачів усіх рівнів якісною освітою в онлайн-форматі в умовах світової пандемії.

Мета статті - представити цифррові інструменти для роботи вчителя в умовах змішаного та 
дистанційного навчання, поділитись досвідом їх практичного застосування та продемонструвати можливості цифрової трансфрормації освітнього процесу на прикладі реалізації дистанційної освіти у Тернопільському національному педагогічному університеті імені Володимира Гнатюка (ТНПУ).

Виклад основного матеріалу. Під час організації дистанційного навчання у ТНПУ було визначено необхідність структурованого підходу до класифікації цифрових засобів навчання, комплексного вивчення проблеми використання цифрових інструментів. У період навчання на карантині викладачі поставили перед собою завдання продемонструвати студентам і практикуючим вчителям, як раціонально створювати 3 доступних ресурсів онлайн власні професійні портороліо чи цифрові кейси для організації успішного навчання у дистанційному фрорматі.

Із цією метою на базі кафредри інформатики та методики її навчання та Центру дистанційного навчання ТНПУ було проведено цикл навчальнометодичних вебінарів з питань організації навчання у дистанційній фрормі та вибору необхідних цифррових інструментів для забезпечення якісного освітнього процесу.

Викладачами кафедри визначено ряд критеріїв до вибору цифрового забезпечення для роботи вчителя:

1) доступність та сумісність програмних засобів та додатків - можливість використовувати такі інструменти в дистанційному фрорматі вчителям і учням незалежно від технічних характеристик комп'ютерів чи інших гаджетів, встановлених операційних систем та мобільних платорорм;

2) відповідність та універсальність - можливість застосування тих чи інших цифрових засобів навчання різними категоріями користувачів, які б відповідали віковим особливостям учнів, працювали коректно на різних платорормах;

3) зрозумілість та адаптивність - використання тих ресурсів, які мають простий для вивчення інтерфейс, адаптовані до застосування в різних навчальним умовах, є доступними для дітей з особливими освітніми потребами;

4) коректність та безпечність - можливість використання цифрових застосунків, програмних середовищ з вільною ліцензією чи відкритим кодом, що забезпечують користувачам збереження авторських прав та підтримують угоди про нерозголошення даних;

5) академічна доброчесність - можливість офріційно використовувати ресурси для навчання онлайн, створювати та зберігати на відповідних серверах чи хмарних сховищах власні доробки, осріційно реєструючись у навчальних середовищах чи працюючи в межах корпоративних угод між розробниками на освітніми закладами.

Відповідно до визначених критеріїв для допомоги вчителям в організації та проведенні уроків у режимі онлайн було визначено такі категорії цифррових інструментів:

1) цифррові платфрорми - середовища розміщення ресурсів для повноцінного фрункціонування навчального процесу в фрорматі онлайн;

2) засоби комунікації та забезпечення зворотного зв'язку - інструменти для налагодження зворотнього зв'язку, проведення фрорумів, вебінарів, конореренцій;

3) інструменти для пояснення нового матеріалу - мультимедійні засоби для інформування здобувачів освіти, демонстрації навчальних презентацій, дослідів, експериментів;

4) засоби для створення інтерактивних завдань - програмні середовища для створення інтерактивних вправ, плакатів, пазлів, ребусів, кросвордів, ігрових проєктів, ментальних карт;

5) тестові середовища - програми для створення бази тестових запитання 3 метою проведення тематичного, модульного, підсумкового контролю, проведення навчальних ігрових тестів чи задля фоормувального оцінювання;

6) навчальні лабораторії - віртуальні мультимедійні навчальні середовища для організації проведення досліджень та експериментів;

7) віртуальні тренажери - програмні застосунки для вивчення програмування, розробки чат-ботів.

Із метою ефективної організації комунікативного простору 3 повним навчально-методичним забезпеченням для повноцінного та ефективного проведення занять в умовах пандемії у ТНПУ використовують платформу Moodle, яка стартувала з 2005 року для розробки та впровадження електронних навчально-методичних комплексів (ЕНМК), які застосовувались до пандемії як доповнення до лекційних та практичних занять в очному форматі навчання.

На платорормі Moodle можна використовувати такі блоки: спілкуватись через чати та фроруми; завантажувати фрайли; вести електронний журнал оцінок; вносити нотатки у календар подій; анонсувати події у блоці новин; розробляти блоки завдань для студентів, створювати власну базу тестових запитань або проводити онлайн-тестування; користуватись Вікі-довідниками, створювати інтерактивні завдання, кросворди, глосарій курсу, долучати користувачів до відеоконореренцій через вбудовані лінки. Кожен ЕНМК викладач наповнює необхідними для роботи блоками особисто відповідно до затвердженої структури навчальних курсів у ТНПУ (рис. 1).

Система Moodle $€$ відкритою платфрормою, на базі якої легко інтегрувати такі засоби комунікації, як Zoom-конференції або вебінари, Big Blue Button чи Google Meet, для індивідуального обміну повідомлення можна використовувати чат або створювати форуми, тому робота з даною системою спрощує для вчителя керування та організацію дистанційного навчання. 


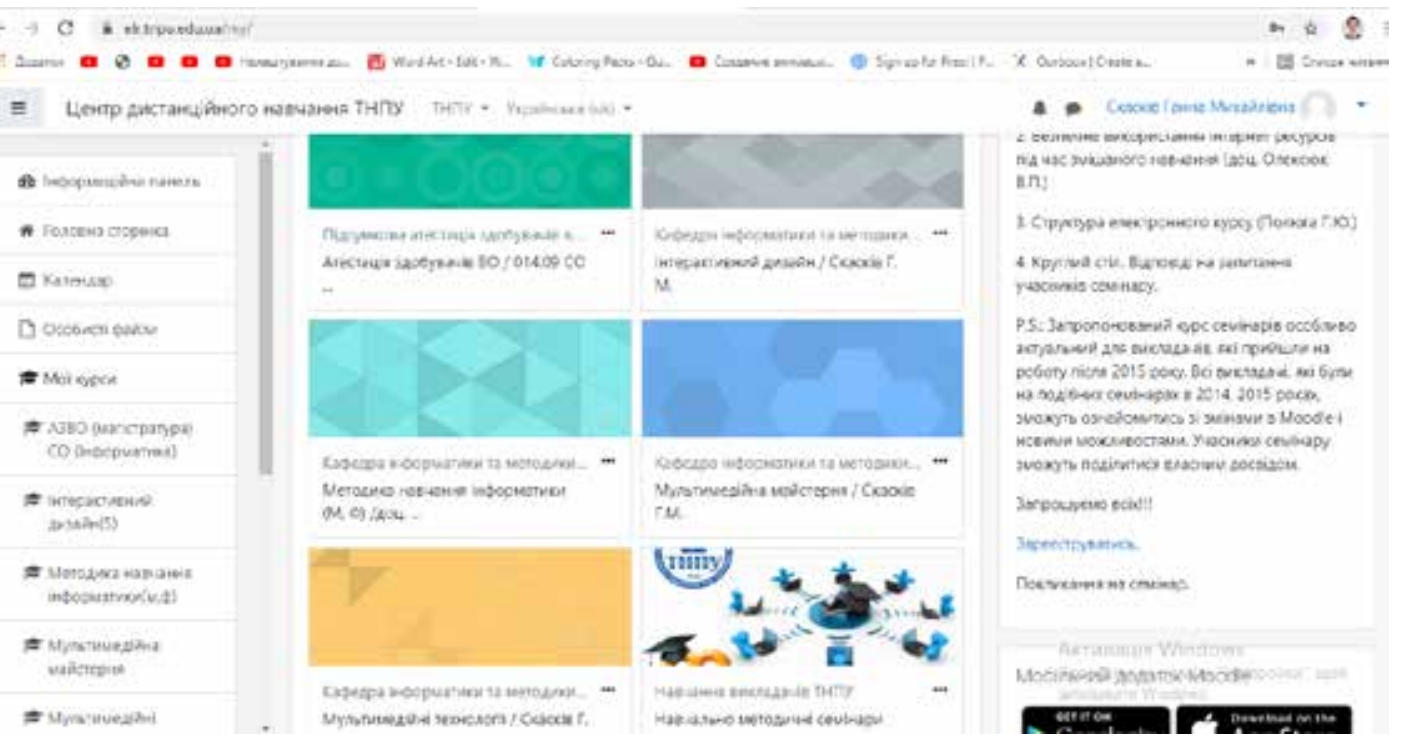

Рис. 1. ЕНМК на платформі Moodle ТнпУ

Під час роботи Дистанційного освітнього транссрерного містечка інноваційних можливостей у Тернополі викладачі касредри інформатики та методики ії навчання ТНПУ, спираючись на рекомендації $\mathrm{MOH}$ щодо організації дистанційного навчання [5], представили не лише вчителям інсрорматики, а й фрахівцям з різних начальних дисциплін добірку цисррових інструментів, які можна використовувати як допоміжні засоби в організації дистанційної освіти.

Для забезпечення зворотнього зв'язку між студентами, учнями та вчителями можна використовувати індивідуальні та групові чати, форуми на платорормі Moodle, групові месенджри Viber, Instagram чи Telegram, що дає можливість швидко повідомляти про завдання, реагувати на запитання, проводити консультації онлайн. Єдина вимога і засторога - чітко регламентувати правила спілкування, кількість і тривалість консультацій. Задля більш динамічного спілкування пропонуємо проводити віртуальні зустрічі у фоорматі вебінарів чи конференцій засобами Zoom, Google Meet, Google Classroom чи Big Blue Button.

На платорормі Zoom вчителю достатньо створити власний обліковий запис, тоді можна легко організовувати та проводити з учнями відеоконференції тривалістю в 40 хвилин. Програму легко завантажити з офріційного сайту на комп'ютери, що працюють під операційними системами Windows чи MacOS, та мобільні телесонии з Android та IOS, завдяки вбудованому плагіну діти легко можуть відкрити її в браузері Google Chrome чи Mozila Firefox. щоб забезпечити високий рівень захищеності усім учасникам, учителю достатньо створити зал персональної конференції, налаштувати авторизоване підключення через персональний лінк та пароль.

До інструментів наступної категорії можемо віднести програмні середовища для створення комп'ютерних презентацій MS Power Point i Prezi та віртуальних інтерактивних дошок (ВІД). Для пояснення нового матеріалу, презентування завдань в ігровій формі доцільніше використовувати слайдові презентації MS Power Point, для проєктної роботи, розробки тематичних блоків і розділів концептуальні 3D-презентації Prezi, окрім цього, дане середовище дає можливість проводити стрім відеотрансляцію під час представлення роботи, доповнювати її інфрографрікою.

ВІД учитель може використовувати як для інфрормування учнів, розміщення завдань, так і організації групової роботи, налагодження зворотнього зв'язку, проведення мозкового штурму 3 учнями, виконання спільної побудови. Сфери застосування ВІД подано на рис. 2.

Серед корисних інструментів для створення інтерактивного цифррового контетнту окремо варто виділити такі: онлайн-сервіс LearningApps, в середовищі якого можна створювати, зберігати та використовувати інтерактивні вправи, дидактичні картки, тестові завдання 3 усіх навчальних предметів для чотирьох категорій: дошкільнят, молодших школярів, учнів середніх та старших класів; ThingLink - це середовище, яке дає можливість створювати інтерактивні плакати з мультимедійним вмістом через позначення кожного об'єкта окремим інтерактивним маркером. Для розробки власних інтерактивних підручників вчителям зручно буде використовувати такі сервіси, як OurBoox або Canva, засобами яких можна змоделювати цифровий кейс з добіркою теоретичного матеріалу, графічними об'єктами, відео- та аудіоконтентом, поєднати їх з авторськими блогами чи каналами.

Для проведення тестового контролю можна використовувати тестер на платформі Moodle, на базі якого можна створювати тестові запитання 


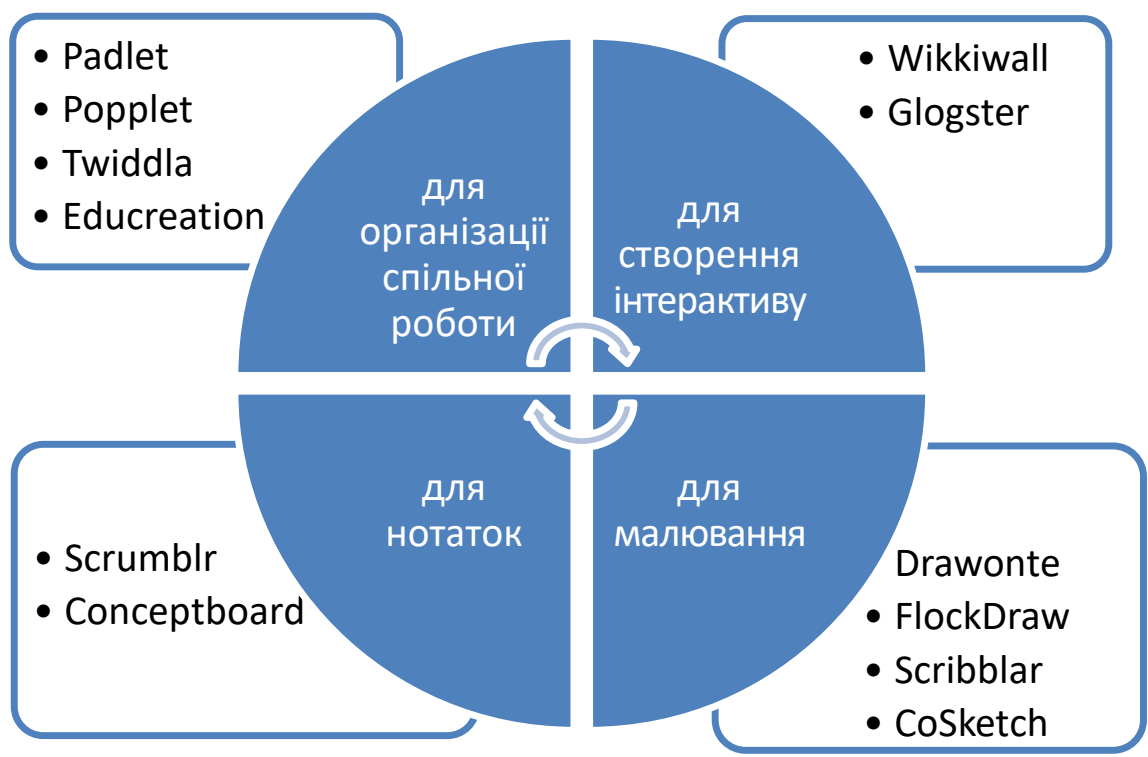

Рис. 2. Сфрери застосування ВІД

відкритого типу, з однією чи кількома варіантами відповіді, на встановлення відповідності, есе. Для формувального оцінювання зручно користуватись можливостями середовища Kahoot, робота 3 яким допоможе вчителю і учням визначити прогалини у знанням. Для перевірки практичних навичок, проведення тематичного контролю або самоперевірки учнів можна використати середовище Plickers чи онлайн-опитувальник Google Forms.

Багатофункціональними цифровими інструментами є мультимедійні віртуальні лабораторії та тренажери, виконання завдань в яких допомагає учням змоделювати реальні процеси, провести експерименти, які часто складно або неможливо виконати в реальному житті. Корисним у роботі стане PhET - програмний засіб під ліцензією GNU/ GPL, у якому запропоновані віртуальні лабораторії, що демонструють різноманітні явища з фрізики, хімії, біології геології, а також інтерактивні математичні інструменти. у каталозі знаходиться декілька сотень різного рівня моделювань, частина 3 яких присвячена новітнім дослідженням.

Використання кожного з описаних цифрових інструментів може слугувати лише допоміжним засобом для покращення якості навчання в умовах дистанційної освіти. Беззаперечною і головною складовою успіху є професійна майстерність вчителя, вміння правильно організувати роботу 3 класом та розподілити рівномірно навантаження для учнів. Щоб уникати фрізичного перенавантаження школярів, завучам та вчителям при складання розкладу занять онлайн варто чергувати роботу в синхронному та асинхронному форматах, що допоможе учням продуктивно працювати впродовж усіх уроків.

Висновки. Швидка адаптація до дистанційного фрормату навчання та успішне поєднання різних фрорм організації освітнього процесу в ТНПУ під час пандемії дає підстави стверджувати, що на практиці можна реалізувати якісно навчання в режимі онлайн тільки за умови конструктивного підходу до процесу організації, поєднання занять в синхронному та асинхронному форматі й раціонального вибору навчальних середовищ та цифрового інструментарію вчителя. У сучасних умовах зростання нового покоління учнів діджиталізованого суспільства основне завдання вчителя та школи полягає не тільки в передачі базових теоретичних знань, фрормуванні ключових компетентностей, а й у створенні сприятливого навчально-комунікативного простору, що допоможе школярам критично оцінювати цифрові ресурси і використовувати для професійного розвитку.

\section{БІБЛІОГРАФІЧНИЙ СПИСОК:}

1. Балик Н.Р., Шмигер Г.П. Методологія фрормування цисрових компетентностей у контексті розробки цифрового контенту. Фізико-математична освіma. 2018. 2(16). С. 8-12.

2. Генсерук Г. Мартинюк С. Розвиток цифррової компетентності майбутніх учителів в умовах цифрового освітнього середовища закладу вищої освіти. Інноваційна педагогіка. Випуск 19. Т. 2. 2019. C. $158-162$.

3. Гриневич Л., Морзе Н., Бойко М. Наукова освіта як основа фрормування інноваційної компетентності в умовах цифрової трансфрормації суспільства. Інформаційні технології і засоби навчання. 2020. Том 77. № 3. С. 1-26.

4. Іванюк І., Овчарук В. Відповідь українських вчителів на COVID-19: виклики і потреби використання цифрових інструментів дистанційного навчання. Інформаційні технології і засоби навчання. 2020. Tом 77. № 3. С. 282-291.

5. Організація дистанційного навчання в школі: методичні рекомендації MOH. URL : https://mon.gov. ua/ (дата звернення: 25.10.2021). 